\title{
MEET THE STATE SECURITY: LABOUR ACTIVISTS AND THEIR CONTROLLERS \\ Ivan Franceschini
}

$O_{1}$

'Brien was a person who could be talked to. Perhaps one did not want to be loved so much as to be understood. O'Brien had tortured him to the edge of lunacy, and in a little while, it was certain, he would send him to his death. It made no difference. In some sense that went deeper than friendship, they were intimates: somewhere or other, although the actual words might never be spoken, there was a place where they could meet and talk.

— George Orwell, 1984

The year 2016 was very difficult for labour rights in China. In order to support investments during a serious economic slowdown, local authorities in several areas froze minimum wages and reduced the percentages of social security contributions shouldered by companies. At the same time, officials in the highest echelons of the Party-state repeatedly criticised the existing labour legislation, in particular the 2008 Labour Contract Law 劳 动合同法, for harming the flexibility of the labour market and constraining productivity. All of this has translated into increased control over those Chinese labour activists who try to promote the cause of workers' rights, as well as the foreign donors who support their activities. This has been achieved through several state bodies, including the State Security guobao 国 保 - a secretive branch of the Public Security apparatus charged with protecting the country from domestic political threats. 


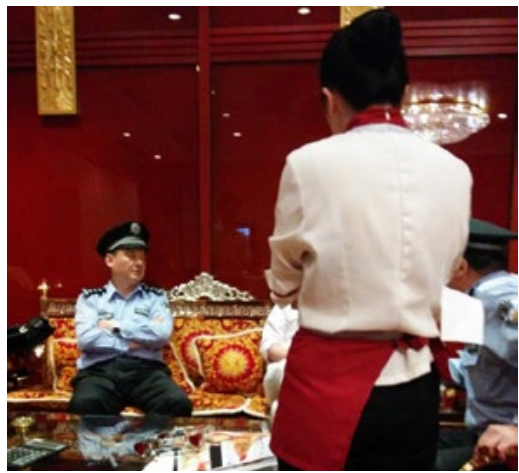

A candid shot of one of China's mysterious guobao Photo: Jianqing Peng, Flickr

At my first meeting with an agent of the State Security in December 2010, I had gone to the office of a little-known labour NGO in the suburbs of Shenzhen to interview some activists. When I arrived, I found a plump, bespectacled guy of around forty waiting for me. Nobody thought about introducing him and he definitely did not make an effort to make himself familiar: for me, he was only 'Mister Wang'. Sitting in silence in a corner, he wrote down on a notebook everything I was saying.

He was a very destabilising presence. Not only did I not know what I should say and what I should avoid, but I was also worried about the trouble I might be causing for my hosts. Besides, I wondered, why did he not use a recorder? Writing down by hand all that was said was indeed a strenuous job and, perhaps as a reward for his effort, he thought it fitting to invite himself to the restaurant for a post-interview lunch - at my expense.

My second brush with the State Security came some time later and it was much more worrying. While I was back in Italy for a few weeks, some guobao officials tracked down one of my former collaborators and interrogated him at length about my activities and whereabouts. I heard much later that they were particularly interested in how I spent money: did I often rent expensive cars? Did I throw money around? He protested that I was so stingy that I always insisted on taking a bus, even when doing interviews in some faraway suburb - which was true - and the matter seemed to rest there.

Being a foreigner, I had little reason to fear the consequences of these encounters: at worst, they would deny me a visa or expel me from the country. But what about those Chinese labour activists who have to deal with the security forces of the Chinese state on a regular basis? How do they manage? 


\section{Sticks}

As with other civil society activists, invitations to 'have a cup of tea' 喝茶 with State Security officials are one of the most common occurrences in the life of a Chinese labour activist. The frequency of these summonses depends on the political circumstances. It usually intensifies around the time of politically-sensitive meetings (such as the annual National People's Congress in March every year); anniversaries (including both official ones, such as the foundation of the Communist Party and unofficial ones, such as 4 June); or major international events hosted in China. The frequency declines in more ordinary times, down to one meeting every several months.

These encounters generally do not entail physical violence. They serve a twofold purpose. On the one hand, officials seek information about the activities of labour NGOs: recent contacts with foreigners and any new sources of funding, for example. On the other, they use the meetings to warn, inform or remind activists about boundaries they must not cross if they want to avoid severe repercussions. From this point of view, these gatherings can be considered mutually ben- eficial: the Party-state gets to remind labour activists that they are under surveillance, while activists benefit from a direct line to the authorities and are able to avoid unnecessary risks if their activities are too close to the limits of what is allowed. One labour activist in East China told me that when he set up his organisation '[the people from the State Security] came to me several times. First, they established a baseline and a framework, warning me to stay within these boundaries. They said that if I did that, all would be good, that I would even be helping the government and the country. If, on the contrary, I crossed that line, for instance by telling foreigners some things that I shouldn't say about our country or our government ... that would have meant real trouble.'

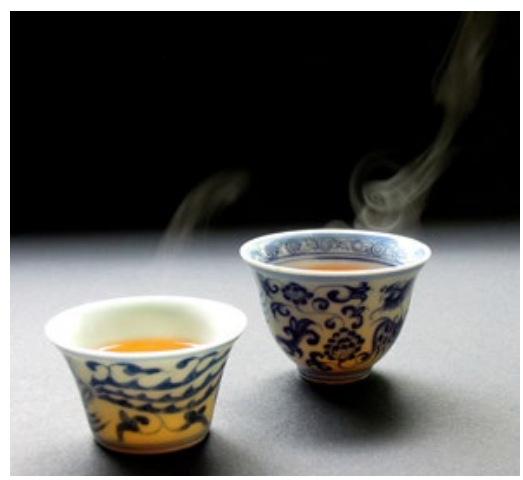

Have a cup of tea

Photo: Matthew Wild, Flickr 


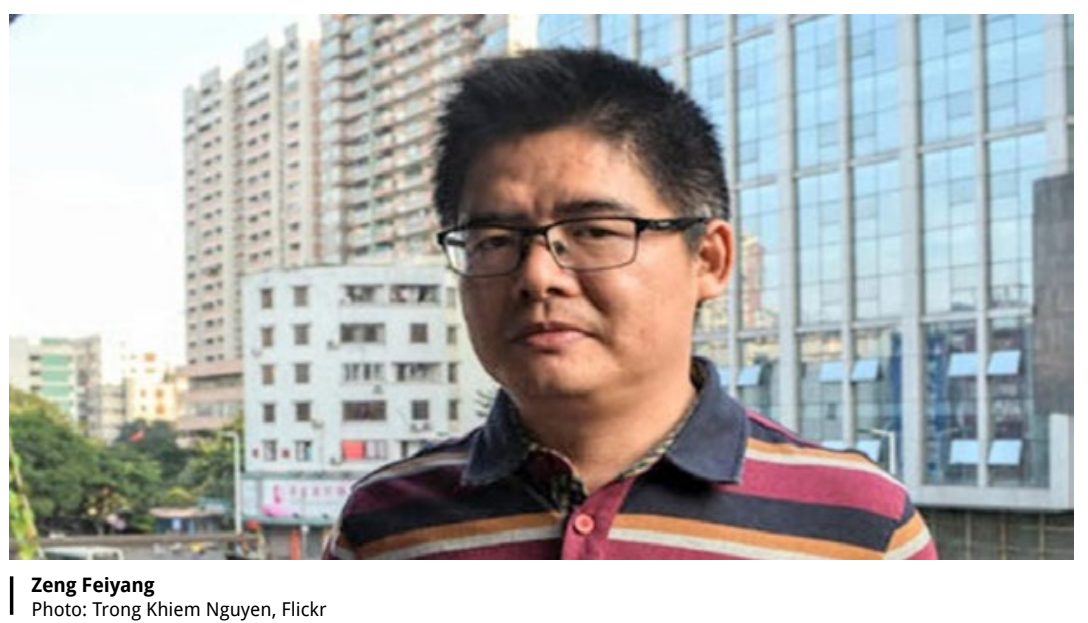

Still, the messages relayed by the authorities are not always reliable. For instance, in 2015, a labour activist in a metropolis in South China decided to test the claim of the guobao that his activities would be tolerated so long as he did not accept any foreign funding. This is what he found out: '[They] had told me that we could work on protecting the rights of workers and that we could organise training on collective bargaining, but that we could not receive funding from abroad. They said that foreigners have a different way of thinking, that if they say something, they actually mean something else, and that they could easily manipulate me ... . They said that if we didn't take any funding from abroad our situation would be better, that they would stop harassing me. I decided that this year [2015] I would try and see whether they were serious. In January, I sus- pended this project [supported with foreign funding], but in these first six months I have already been forced to move [office] three times.' In light of this, he decided to resume his cooperation with foreign donors.

Whatever assurances the State Security might provide in individual meetings, these encounters do not always go smoothly, as the highest echelons of the Party-state tend to consider labour NGOs as covert agents of 'hostile foreign forces' eager to wreak havoc in China. Although largely predating the latest change of leadership, this narrative has gained much more currency since Xi Jinping came to power. According to one activist whom I interviewed back in 2014 in a second-tier city in Guangdong province: 'After President $\mathrm{Xi}$ came to power, the management and control of NGOs has become increasingly strict. 
Recently, people from Public Security came to meet with us. They asked what our political standpoint was and said that all the "coloured revolutions" abroad were instigated by NGOs and then they asked our opinion about it. I replied that we don't pay too much attention to this [sort of thing].'

\section{Mounting Pressures}

Agents from State Security may also resort to psychological intimidation and other tactics to persuade labour activists to cease their work. In the past few years, guobao officials have repeatedly pressured landlords to evict NGOs from their premises. They have also liaised with other branches of the Party-state - such as those in charge of family planning, tax or social security bureaus, as well as universities, etc. - to harass the activists and their families. They have even intervened behind the scenes to freeze bank accounts or prevent people from leaving the country. As an activist in southern China told me in November 2014: 'In the past, they didn't provoke us, nor did we provoke them. Basically, what we had back then could not even be called repression. Usually, they just knew about the existence of our organisation and there were often peo- ple from the government who came to talk with us ... . But these last few years have been quite different, they have started to harass us directly.'

While life for Chinese labour activists has never been easy, 2016 has been a real annus horribilis for them. The latest wave of repression started in December 2015, when Chinese authorities rounded up dozens of labour activists in Guangdong and then charged five of them for 'gathering a crowd to disrupt public order' and 'embezzlement'. This coincided with a systematic harassment of Chinese civil society, with the closure of many NGOs working on social issues, and the arrest or outright disappearance of several public interest lawyers. On that occasion, the Party-state targeted Zeng Feiyang 曾飞洋 — leader of a pioneering labour NGO in Guangzhou in an unprecedented smear campaign. A series of devastating reports accused Zeng of embezzling funding illegally obtained from foreigners and of acting out of personal greed, without any regard for the interests of the workers. To further destroy his credibility, he was also accused of several instances of sexual misconduct. ${ }^{1}$

Zeng pleaded guilty and was sentenced to three years in prison - sus- 


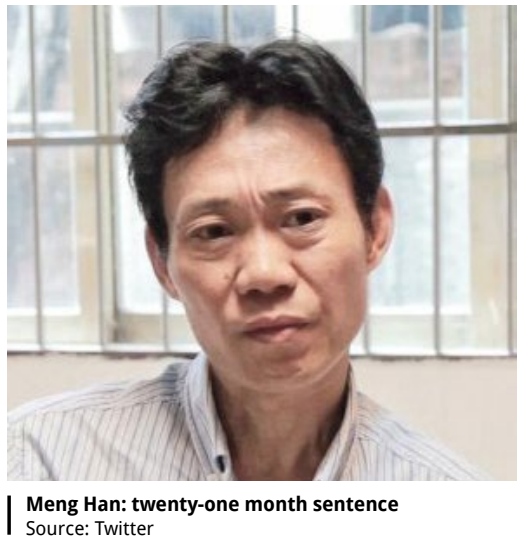

pended for four years - for 'gathering a crowd to disrupt public order', while two of his colleagues received prison sentences of eighteen months - suspended for two years - for the same crime. Meng Han 孟晗, another activist in the same organisation, refused to co-operate. Only after repeated harassment of his parents did he finally capitulate and plead guilty, and was sentenced to twenty-one months in jail. Zeng's admission of guilt at the trial was quoted in full by the Chinese media: 'I apologise for the losses that my criminal actions have caused to companies, society, and workers, and I express deep sorrow for the enormous wounds that I have inflicted on my family. I hope that everybody will take me as a warning and that they will not be fooled by any foreign organisation, [keeping in mind] that they must resort to legal means and channels to protect their rights and interests.'2

\section{Carrots}

The relationship between labour activists and their controllers is not always so thorny. I recall my surprise when, about five years ago, an activist I used to know quite well told me that while he was recovering from surgery, the State Security official in charge of him had visited him in the hospital. Wishing him a speedy recovery, the guobao had brought him flowers and they had engaged in amiable conversation. The activist explained that, since this official had been his 'supervisor' for quite some time, they had become almost friends, regularly exchanging greetings and wishes on all major Chinese festivals.

Such ambiguous feelings are not surprising considering that some activists are supervised by the same officials for years. The relationship may also offer some perks. As one activist in southern China recently told me: 'We can say that they are old acquaintances... . On the surface they are friendly, but in fact we don't really know what they think about us, we just tell 
them what we have to ... . Sometimes they also offer us some gifts [such as shopping coupons], which obviously we don't accept ... . But it seems that in recent years they have become poorer, they don't have as much money as before.'

In some cases, less scrupulous activists have exploited their connections to the State Security as leverage in their relationship with foreign donors. In 2009 and 2010, I was working as a manager on a project in partnership with a local labour NGO that turned out to be quite notorious for its record of fake activities and inflated invoices. When I refused to reimburse an obviously dodgy expenditure, the leader of the NGO hinted that he would say something rather unpleasant about me in his next meeting with the authorities. On another occasion, someone who had been fired from the same organisation decided to seek compensation directly from the foreign donor,

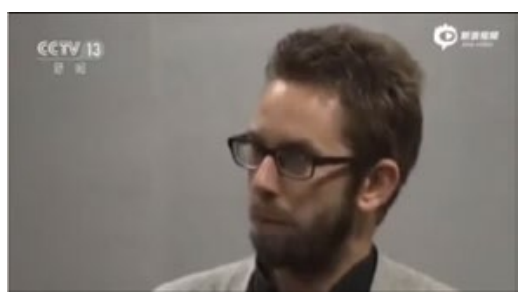

Peter Dahlin during his televised confession Source: YouTube threatening to talk with his 'friends' in the security apparatus if he did not get what he wanted.

\section{What Next?}

Control over NGOs is increasing, as is repression, and this extends to foreigners who are involved with them. In the past couple of years, a few expats in China with ties to foreign and local NGOs have been detained, with one of them - Peter Dahlin, a Swedish citizen - even being paraded on national television in early 2016, confessing to inciting 'opposition to the government.' But it is Chinese activists who bear the brunt of the Party-state's ire. Labour activists, as well as human rights lawyers, are among those most at risk in the current political climate. Even more worrying than brutal repression is the recent adoption of a whole series of new laws and regulations aimed at bringing civil society under control. Most notably among these is the new Law on the Management of Foreign NGOs' Activities 境外非政府组织境 内活动管理法, effective from 1 January 2017, which will basically cut off any access to financial support from abroad for NGOs active in sensitive fields such as labour or human rights. 
Almost all the labour activists that I have encountered in the past few months say that they are willing to keep up the fight, undeterred. At the same time, however, they cannot help but wonder how they will be able to survive as their sources of financial support quickly dry up and even finding enough money to pay their staff or the office rent becomes increasingly problematic. A few months ago, for the first time in many years of regular encounters with labour activists, I was asked by the leader of a once-prominent NGO, now in serious financial constraints, to help by sending some funding - 'really, any amount counts' - to an account opened under the name of one of his friends. If this is going to be the 'new normal' during Xi Jinping's tenure, then activists might start reminiscing about the golden age when the most that State Security did was to invite you for a cup of tea. 
This text is taken from China Story Yearbook 2016: Control, edited by Jane Golley, Linda Jaivin and Luigi Tomba, published 2017 by ANU Press, The Australian National University, Canberra, Australia. 